\title{
A Place on Mulago Hill
}

The memoirs and other writings of missionaries, travellers and physicians in colonial Uganda are full of accounts of the powerful impression western medicine made on the 'native' mind. Cures for syphilis by injections of Salvarsan '606', or of procedures to remove cataracts, were credited with helping to convince Africans of the benefits Europeans could bestow, whether in the form of Christianity or 'civilisation'. As Church Missionary Society (CMS) doctor Albert Ruskin Cook recalled on his earliest surgeries, which were performed in front of audiences: 'Anaesthetics were at first a great marvel; on seeing no sign of pain while extensive wounds were inflicted and large tumours etc. removed with the necessary loss of blood, some thought we had killed the patient. On the effects of the anaesthetic passing off and the suffering exhibiting signs of life, some credited us with raising the patient from the dead'. ${ }^{1}$ While such self-congratulatory and often patronising accounts were common among medical missionaries and physicians, few made such bold claims about mental illness. This was due in part to the invisibility of mental cases, more frequently cared for at home, leading some Europeans to question whether mental disorder existed as a distinct disease category in Africa, separate from organic disease. But it was also linked to an awareness that western medicine had little to offer by way of therapeutic hope, particularly as explanatory frameworks for understanding and treating mental illness were so different. It was a rare boast for Philip Hutton, at Mulago Hospital from 1937 to 1961, to recall how:

(C) The Author(s) 2019

Y. Pringle, Psychiatry and Decolonisation in Uganda, Mental Health in Historical Perspective, https://doi.org/10.1057/978-1-137-60095-0_2 
One of the views held by local Africans was that there were two kinds of illness:- Those which could be cured by injections and those which were only amenable to 'native medicine' i.e. the practise of witchdoctors. Those would have appeared to be of a psychological or psychiatric nature. On one occasion having 'cured' a case of hysterical blindness with suggestion assisted by pentothal I was constantly being stopped and congratulated by members of staff for having cured an 'African' disease with an injection. ${ }^{2}$

The history of psychiatry in colonial Uganda reflects this marginal nature of psychiatry within broader systems of healing, as well as within the colonial medical hierarchy. Psychiatry existed in Uganda not because it was particularly useful or effective, but because it was regarded by the colonial administration as a logical method of dealing with madness in a civilised society. Charles Baty, Superintendent of Mulago Mental Hospital, expressed this sentiment in a lecture to mental hospital attendants in the early 1940s. He described how 'Many years ago there were no Mental Hospitals in Africa and mad people just went walking about and sometimes died, and sometimes they killed people and set fire to houses and stole and did damage to other peoples [sic.] property'. ${ }^{3}$ 'Sometimes', he added, 'they were caught and chained up in a little house and kept there until they died or got better'. ${ }^{4}$ Yet these conditions were 'very troublesome both for the people who look after mad people and for the mad people themselves, so Uganda like all other African countries came to have a Mental Hospital because lunatics are less troublesome and the country is much safer when lunatics are kept in a place by themselves where they are properly looked after and where they will have the best chance to recover'. ${ }^{5}$ For Baty, the establishment of institutions for the confinement of the mentally ill was a sign of progress and of the benevolence of British rule. It was a narrative that presupposed a unity and purpose to psychiatry that privileged the power of individual psychiatrists and ignored the multiple ways psychiatry was used and contested by patients and their families.

In colonial Uganda, 'psychiatry' consisted for the most part of a fragmented group of prison warders, hospital attendants, and African and European doctors who declared authority over the mentally ill. In the archival record, it is their voices that predominate, with the identities and experiences of patients obscured-reduced to statistical tables or anonymised objects of treatment. With patient case notes from the early days of Mulago Mental Hospital having been lost or destroyed, we 
now know more about the brands of electroconvulsive therapy (ECT) machines used at Mulago Mental Hospital, and the numbers who underwent treatment, than we do about the lives of those who were confined. But the rare glimpses we do have of patients-in surviving court records, annual reports and administrative correspondence-point to their creativity and resourcefulness, whether through challenges to the legal system, refusing to maintain order, or by resorting to hunger strikes. Such instances, often little more than archival echoes, remind us that colonial psychiatry was not an all-encompassing force. Not only was there no 'great confinement' in Africa to match that of nineteenth-century Europe, as Megan Vaughan has shown us, but as a system of practices which sought control over bodies and minds, the power of colonial psychiatry was limited. ${ }^{6}$

The broader story told in this chapter is, in many ways, an unexceptional one within colonial Africa. Between 1894 and 1962, the dates of formal colonial rule in Uganda, provision for the mentally ill evolved from the occasional and haphazard isolation of troublesome lunatics to an established (if often flawed) system of certification, confinement and repatriation. The perception that the mentally ill would be best treated at Kampala, coupled with a series of scandals, forced the colonial government's Medical Department to acknowledge responsibility for the mentally ill. If there was no overarching scheme for psychiatry, however, it was not because it was isolated from wider medical, social or political trends. One of the most distinctive features of western medicine in early colonial Uganda, for example, was the strong medical missionary presence. In the period before 1940, medical practice was marked by a high level of collaboration between mission doctors and the Colonial Medical Service, with a number of CMS doctors negotiating dual roles as missionaries and colonial medical officers. ${ }^{7}$ An even greater number participated in and managed government health campaigns or were engaged unofficially by the administration in an advisory capacity. When the colonial government sought advice on the development of psychiatry from the 1920s, they turned to medical missionaries, notably the CMS doctor Albert Cook, for advice. ${ }^{8}$ In the longer term, however, it was the colonial government's interest in medical training that would have significant implications for psychiatry. As seen through the development of a medical school at Mulago Hospital from 1923 (referred to as Mulago Medical School from 1927 and Makerere Medical School from 1939), the training of Africans in medicine soon came to dominate 
colonial medicine in Uganda and, for some doctors, was a point of pride. ${ }^{9}$ While European doctors did not always regard their African colleagues as equals, they nevertheless believed that their training programmes set Uganda apart as more 'liberal' than other colonies, and in particular from Kenya. ${ }^{10}$ The ways that African doctors occupied complicated and often ambiguous positions within the power structures of psychiatry is explored in Chapter 3. Most important for the purposes of this chapter, however, was the nature of colonial rule in Uganda. Unlike Kenya, Uganda's neighbour and oft-looked to point of comparison by colonial officials, Uganda did not have a large European population. While the opinions of Europeans, particularly those living in the main area of European residence, Kampala, were often considered, the colonial government did not have to accommodate the demands of a powerful settler community. This was significant for psychiatry because it meant that the development of what we might deem to be institutions of 'social control', and associated legislation and policy, were less urgent. Hoima Asylum was formally opened in 1921, almost thirty years after the establishment of the Uganda Protectorate in 1894, and significantly later than Kenya's Mathari Asylum, which opened on the outskirts of the Nairobi Municipal Area in 1909. ${ }^{11}$ Also reflective of the small European population was the minimal provision made for European patients, even after the opening of Mulago Mental Hospital in 1935. These features fed into the predominantly reactive nature of psychiatry in colonial Uganda: changes to policy, or to buildings and accommodation, frequently occurred following a perceived problem created either by a European or African patient.

This chapter, which focuses on psychiatry under colonial rule, is included within this book because it sets up the institutions and practices that were inherited by a newly independent Uganda in 1962. The low priority accorded to psychiatry, expressed through minimal financial resources and few specialist personnel, was cemented during this period, and proved difficult for psychiatrists to change after Independence. It was also during this period that the most enduring stereotypes and assumptions about psychiatry were formed and hardened: the language of 'lunacy' and 'persons of unsound mind', the notion of psychiatry as a last resort for only the most 'difficult' or 'violent' cases, and of the mental hospital as an alienating place, where communication was difficult, if not impossible. Yet at the same time, I aim through this chapter to highlight the marginal nature of psychiatry—a recurring theme throughout 
the book. Those suffering from mental distress, and their families, continued to make decisions about care and treatment that were often unconnected to government or psychiatric policy.

\section{From Hoima to Mulago}

In 1901, brothers and fellow CMS doctors Albert and Jack Cook notified the colonial government and the medical community in Britain of concerns over the growing number of sleeping sickness cases arriving at the CMS Mengo Hospital, Kampala, sparking international interest in a disease that was to devastate local communities on the shores of Lake Victoria. ${ }^{12}$ The role assumed by the mission doctors at Mengo Hospital, and the manner in which they informed and advised the Colonial Medical Service, was to shape medical practice in Uganda, including that related to mental illness, for the next thirty years. The epidemic, which killed an estimated 250,000 people, prompted the forcible depopulation by the government of areas infested with tsetse flies, the establishment of government sleeping sickness camps, and the rapid development of a Colonial Medical Service aimed at understanding and limiting the disease. ${ }^{13}$ Given this context, it is unsurprising that early discussion of mental pathology in Uganda was linked to sleeping sickness. Preoccupied by the volume of sleeping sickness patients who exhibited signs of mental degeneration, other types of mental illness were rendered almost invisible. As the author of an early draft of the colonial Blue Book of 1908-1909 commented: 'Mania and dementia apart from [in] sleeping sickness are so uncommon that their presence leads to the suspicion of the existence of that disease'. ${ }^{14}$

Special provision for late-stage sleeping sickness patients within government camps pre-dated the establishment of a lunatic asylum by over twenty years. These patients frequently exhibited violent or unpredictable behaviour, and as such their separation was deemed necessary for camp security. Following a visit to the camp at Kyetume, just over four miles from Mukono, central Uganda, in 1909, Albert Cook described how 'One compound was set apart for the treatment of maniacal cases, and here were half a dozen or so who had their legs shackled together to prevent them doing harm to themselves or others. They seemed far from melancholy'. ${ }^{15}$ Writing for a similar audience, J. C. M. Baker, wife of a Medical and Sanitary Officer and camp administrator, recounted how one night: 'New sounds bore into my brain, ears are awake and 
strained instantly. Cries far away, quick, high-pitched, lapping over each other like ripples - the cries of alarmed natives'. ${ }^{16}$ While in its late stages, sleeping sickness can result in mania, instances of 'difficult' behaviour, aggression and attempts to escape by detainees were consistently labelled as insane or 'irrational'. In the written record at least, little reflexivity or agency was allowed, despite widespread recognition that sleeping sickness camps were looked on with 'dread and aversion'. When, in 1909, a large number of sleeping sickness cases 'gave considerable trouble and frequently attempted to set fire to their quarters', the Governor of Uganda, Henry Hesketh Bell, explained away what was most likely a riot by declaring the perpetrators to be 'demented', and arguing for further medical care. ${ }^{17}$

The sleeping sickness epidemic demonstrated to the authorities in Uganda that diseased Africans could be dangerous and unpredictable, but it had little impact on policies towards the mentally ill. When the first Lunacy Ordinance was passed in 1906, it was done to provide a legal basis through which to handle the few European cases of insanity, rather than African patients. ${ }^{18}$ Before this point, the High Court of Uganda had lacked the power to deal with 'several cases of lunacy among white men', including a Police Sergeant diagnosed with general paralysis of the insane (GPI), who needed to be sent back to England 'as soon as possible in order that he may be placed under suitable restraint'. ${ }^{19}$ The ordinance allowed the court to certify cases of insanity following the receipt of two medical certificates, to take possession of and manage property in Uganda, and to make arrangements for custody and care. One of the first Europeans to come under the new ordinance-a senior customs official with the colonial administration-was 'apparently suffering from the effects of some severe shock to his mental system' rendering him 'incapable of managing himself or his affairs'. ${ }^{20}$ As Uganda lacked 'special provision' for 'persons of unsound mind', his invaliding to England was deemed essential, and he remained under the constant supervision of one Medical Officer (MO) while the colonial government fought over who should be responsible for the costs. ${ }^{21}$ Europeans found insane in Uganda would continue to be removed as long as the colonial government or relatives agreed to pay the costs, either for a journey back to England, or to mental hospitals in Kenya or South Africa. ${ }^{22}$ While the colonial government made provision for Europeans within Hoima Lunatic Asylum from 1921 and then at Mulago Mental Hospital from 1935 , the inadequacy of the accommodation and lack of staff meant it 
was considered undesirable to admit Europeans for anything longer than a short period prior to their transfer.

Provision for mentally ill Africans who came to the attention of the colonial administration, primarily through the police, was similarly lacking. Neither the prisons nor the medical service wanted to assume responsibility, seeking ways to avoid the financial and logistical burden as far as possible. By 1913, Hoima Prison, in western Uganda, had developed a reputation as a dumping ground for leper and insane prisoners. ${ }^{23}$ This, according to the Inspector General of Police and Prisons, was unacceptable: 'To intern the demented, the diseased, and those in full possession of their health and senses in one and the same building when that building is lacking the means of complete segregation, is a measure so diametrically opposed to the precepts both of Prison and Medical Administration'. ${ }^{24}$ Numbers were small-there were eleven certified lunatics at Hoima in 1914-1915-but there was minimal medical supervision (the nearest medical officer lived thirty-seven miles away) and inmates who were found to be 'difficult' were 'hand cuffed (or leg cuffed or both) to the bars of the doors of their cells'. ${ }^{25}$ It was not until 1921 that the housing of the mentally ill with prisoners was deemed by the government to be unacceptable on logistical and moral, if not medical grounds. In that year, Hoima was gazetted as a Lunatic Asylum, and in 1923, the general prison population was removed, leaving the 'ordinary' and criminal lunatics in the remaining buildings. ${ }^{26}$

The repurposing of Hoima Prison as a Lunatic Asylum came just as the Colonial Medical Service in Uganda started to be reorganised. In line with growing cotton and coffee trade and a rapidly expanding European population, the colonial administration found themselves faced with the need to increase the size and scope of medical provision at minimal cost. ${ }^{27}$ While one way of achieving this was by harnessing missionary manpower through formal contractual arrangements, the pursuit of 'efficiency' primarily meant centralisation. ${ }^{28}$ Declaring the specialist anti-venereal disease clinics that had been at the heart of both government and missionary medical and morality campaigns since the early twentieth-century as exorbitantly expensive, moves were made to combine general and specialist medical work in all areas. ${ }^{29}$ Here, the CMS Mengo Hospital, which by the mid-1920s had developed into a complex of medical units under one administrative head, served as the ideal model. ${ }^{30}$ As part of their moves to reorganise medical services, the colonial administration put forward a plan for a new 
purpose-built mental hospital in or near Kampala, at the time a growing centre of European residence. This would reduce the amount of travelling required by patients, as well as administrative and medical staff, and allow for easier access to medical facilities. It would avoid, it was hoped, a repeat of a scandal in 1920 that saw two 'harmless lunatics' die after being forced to travel over 140 miles (a distance that took on average two full days by motor-van) from Hoima to Kampala for observation and certification. ${ }^{31}$ Seeking the advice of physicians in KampalaAlbert Cook among them-G. J. Keane, Director of Medical and Sanitary Services (DMSS), suggested two potential sites. The first was at Luzira, a few miles outside of Kampala. While its relative remoteness from European residence would avoid the 'annoyance of the possible noise made by maniacal cases', it was far from other medical facilities in Kampala and close to Luzira Prison. ${ }^{32}$ This, Keane warned, may serve to perpetuate 'the association of ideas which has arisen between crime and lunacy which it is desirable to end'. ${ }^{33}$ The other site, near Mulago Hospital, would by contrast allow 'regular treatment of cases and daily and nightly supervision by medical staff', in addition to savings affected by the sharing of kitchen, laundry and cleaning services. ${ }^{34}$

Discussions about the proposed mental hospital forced the colonial government to consider the management of the mentally ill in more than just logistical and financial terms for the first time. Consideration now had to be given to perceptions of mental patients as noisy, unmanageable and potentially dangerous. This was not linked to large numbers of certified lunatics - at the beginning of 1930, Hoima Lunatic Asylum had only 61 inmates (38 male and 23 female, all African). ${ }^{35}$ Nor was there any public outburst of alarm over the presence of 'raving maniacs' on the streets, as was seen in Nigeria, ${ }^{36}$ if reports of madmen stealing 'a roll of toilet paper from the lavatory', 'placing large stones and sticks across the road', or entering the bedroom of a European woman did occasionally appear in English-language newspapers. ${ }^{37}$ Rather, it stemmed from Hoima's origins as a prison, combined with official policy which, due to limited accommodation, urged that only the most 'urgent' or violent patients be recommended for admission. ${ }^{38}$ All other cases, as DMSS J. Hope Reford stressed in 1926, 'should be handed to their relatives'. ${ }^{39}$

Mulago Mental Hospital was opened in 1935 on Mulago hill, previously home to numerous Kings of Buganda, beyond the edges of European settlement, and host to a growing number of government medical institutions, including Mulago Hospital and its medical school, 
opened in 1923. Mulago marked a compromise between those who wanted the mentally ill to receive specialist medical care and a broader sentiment that a 'screaming raving lunatic should never be exposed to the public'. ${ }^{40}$ Indeed, it was hailed as a most progressive way of dealing with the mad. Modelled on the late nineteenth-century English asylum, it had, on opening, ward accommodation for 72 male and 24 female patients, as well as sixteen single isolation cells. It was set in a grass compound, with day shelters and a small garden, all surrounded by a fence. The Luganda newspaper Gambuze informed readers in a piece of propaganda that the Uganda Government was building a hospital for eddwaliro ly'abalalu (mad people) on Mulago hill 'so the staff of Mulago can look after them'. It called on readers not to take their relatives anywhere else, for 'this will be where the mentally ill will be taken for treatment' ${ }^{41}$ Matalisi similarly described how the colonial government intended to 'bring learned foreigners' to work at this new specialist hospital. The English-language Uganda Herald, meanwhile, proclaimed that 'Like all modern institutions of its kind, the 'padded cell' is done away with as it is understood that really obstreperous patients are treated with drugs'. But, it was careful to add, the wards would be painted with 'special paint' to prevent escapes, all windows would be fastened from the outside, and 'the buildings...so erected that it is not anticipated any noise will be heard by the patients in Mulago [General] hospital' ${ }^{42}$ Such perceptions about noise would prove difficult to overcome. As an anecdote among Mulago Hospital staff in the 1970s relayed, when the site for the mental hospital buildings was chosen, administrators sent 'a large group of hospital employees and their wives on a noisy progress from the General Hospital, and, when their din could no longer be heard...the site for the new hospital was marked! 43

\section{CASES FOR ADMISSION}

The decision to open a new mental hospital at Mulago marked an intention to treat mental illness by 'modern' psychiatric means for the first time. It did not represent a shift in the types of patients deemed suitable for admission, however. Until 1956, admissions to the mental hospital were involuntary, dependent on reports made by chiefs, the police and two medical practitioners, and were determined by a system that continued to prioritise 'unmanageable' and violent cases. ${ }^{44}$ Numbers also grew rapidly throughout the colonial period, with the total number 
of annual admissions rising from 24 in 1935 to 652 (including 26 readmissions) in $1956 .{ }^{45}$ The explanations for this were subject to debate, with some suggesting that rising numbers was evidence of the inability of Africans living in urban settings to cope with the demands of 'civilisation'. ${ }^{46}$ Writing in 1951, Uganda's first Specialist Alienist, George Campbell Young, drawing on the work of J. C. Carothers, argued that 'There are well-founded reasons for believing that the incidence of insanity in Africans living in their natural environment is low. Higher rates of insanity are found in Africans living away from their former tribal areas, and this section of the community is likely to increase in the future' ${ }^{47}$ More logical reasons for rising admissions, however, were increases in the availability of accommodation, changing socio-economic conditions (particularly in Kampala) which were straining the ability of families to care for the mentally ill, as well as the growth of road networks, which made it easier for the police to transport suspected cases to Kampala. Proximity to the mental hospital was a key factor in admission, with the Ganda, the main ethnic group in and around Kampala, as well as Rwandan immigrants, predominating among inpatients. By living close to an urban centre, these patients were not only more visible to the colonial authorities, but could be transported quickly and at minimal cost. ${ }^{48}$ As distances became more manageable towards the end of the colonial period, more patients were brought from elsewhere in Uganda. But the Ganda continued to predominate, comprising 153 of the 558 patients within Mulago Mental Hospital at the end of $1956 .{ }^{49}$ Indeed, even by the 1960s, a town like Fort Portal, two-hundred miles west of Kampala, had only fifty miles of tarmacked road, creating ongoing reluctance to do anything more than leave suspected mental patients in prison, or cared for at home. ${ }^{50}$

Most patients were brought to the mental hospital following violence, arson or, in urban centres, 'wandering'. ${ }^{51}$ This did not mean that the processes of admission were smooth or uncontested, however. Cecil C., a mining engineer who was certified as 'insane' following three weeks of 'alcoholic intemperance' in 1930, was among those who challenged the authority of the police and medical practitioners to diagnose deviant behaviour. While in hospital, according to the official reports, Cecil C. had become aggressive, 'addressing imaginary persons', being 'suspicious of his food', 'filthy' in his habits and 'violent', requiring him 'to be handcuffed to his bed'. ${ }^{52}$ Addressing the judge presiding over his Reception Order case, Cecil C. argued that these statements were false: 'I was never 
handcuffed to my bed for filthy habits as I do not possess filthy habits. I am not and never have suffered from hallucinations. I have never been so idiotic as to tear up pieces of paper and distribute them as cheques' ${ }^{53}$ Going further, Cecil C. charged the police who removed him from hospital to Kampala Gaol with ill-treatment:

On arriving I refused to lie down on the bed. I stood in the doorway with result that I was handcuffed. The cell was locked and I had no attention or a drink for 24 hours. I was never as far as I know reported as being insane. If I was reported, it was done behind my back. In any case there was no second opinion. I therefore resent the reports being made. I shall call the doctors to book. They will have to prove me insane now or face the consequences. ${ }^{54}$

Following the judge's dismissal of Cecil C.'s protestations as to his sanity, he turned his attention to the colonial administration, charging them with undue use of force in restraining him, and threatening legal action. The problem was not so much the ill-treatment, but Cecil C.'s barrage of correspondence, which he kept up much to the consternation of the officials who had to respond to it. Not only did consideration of his claims mean 'time and work for many', but they regarded his 'present attitude' as 'an example of the blackest ingratitude to his custodians', made worse by the fact that he was 'an almost incredible nuisance while under detention... and looking after him was a filthy and horrible business to all concerned'. ${ }^{55}$ While, like the judge, the colonial government ultimately refuted the claims of ill-treatment, Cecil C. nevertheless forced them to consider the lack of provision for European patients. Rather than continue to rely on the prison system, there would need to be adequate provision in Mulago Mental Hospital for the short-term confinement of Europeans.

Harold B., a barrister who had been practising in Kampala since his arrival in Uganda in August 1925, evoked similar annoyance among the colonial government with his complaints. Having been arrested on a charge of attempting suicide towards the end of 1928, he had been certified as suffering from 'chronic delusional insanity' and confined in Kampala Gaol before being transferred to Mathari Mental Hospital, Kenya. While it had been usual practice to remove European patients to either Kenya or South Africa, Harold B. made it clear, in increasingly litigious terms, that there was no real legal basis for his transfer 
or reception in Kenya. While the colonial government admitted, internally, the 'technical illegality of his transfer', they maintained that there was no moral claim to be made: 'He was undoubtedly a madman, and his transfer to the more suitable conditions at Mathari was an act of common humanity'. ${ }^{56}$ Shortly after his arrival at Mathari, Harold B. was transferred to South Africa, where he was confined at Fort Napier Institution, Pietermaritzburg. There, his mental state improved sufficiently to justify his discharge, and he soon sought a return to Uganda. The colonial government refused his return request, declaring that his history of insanity made him a 'prohibited immigrant' and potential burden on the state. This did not deter Harold B., however. Drawing on his legal background, Harold B. started to petition the colonial government first for permission to return to Uganda, and second for compensation in the form of a 'compassionate grant'. This correspondence was full of personal appeals, in which he described his record of service during the First World War, as well as how his 'detention as a lunatic has been a horrible mistake and I have lost five years of my life and of my professional career in consequence' ${ }^{57}$ But it was the repeated references to the legal irregularities of his case, as well as the volume of correspondence, which included a petition to the Secretary of State for the Colonies, that created the most annoyance. It was also not wasted effort. While Harold B.'s claims for compensation were unsuccessful, the colonial government not only eventually conceded his return, but provided him with sufficient funds to do so. ${ }^{58}$ This did not represent a softening of policy-they fully intended, 'from a practical point of view', to do 'all we can to persuade [him] to go straight to the United Kingdom' and, 'if his circumstances justify it', to start proceedings to remove him from Uganda. ${ }^{59}$ Yet Harold B.'s case nevertheless shows that the hard-line stance towards the mentally ill could be successfully challenged.

In contesting decisions relating to their confinement, European patients such as Cecil C. and Harold B. were able to draw on a body of shared knowledge of policy and procedures that would likely have been inaccessible to many of the African patients who made up the majority of psychiatric cases. Even Cecil C., who was aware that he had a right to appeal against his confinement order, complained that he was not allowed to see a legal adviser when he asked to do so. ${ }^{60}$ This is not to say that African patients were not able to contest the authority of psychiatry, however; they certainly were, and did so resourcefully. While court and admissions records are lacking, patient records for the CMS Mengo 
Hospital, which accepted small numbers of suspected cases of mental illness for examination and short-term treatment, show that African patients were just as unlikely to be passive objects of treatment. Sabakaki, for example, was brought to Mengo Hospital at the end of 1938 by 'people who found him in the road'. While he appeared 'reasonably alert and cooperative', he consistently refused to answer any questions, meaning that no history could be taken. Instead, he lay 'quietly in bed - tho' he has been trying to go away'. Four days later, still refusing to 'give an account of himself', he ran away. ${ }^{61}$ While Sabakaki's behaviour could be read as a sign of his irrationality (and it likely was by the doctors at Mengo Hospital), it also represented a refusal to engage in the diagnostic process, and to accept confinement.

The power of psychiatry was further checked by having to negotiate with the families of the mentally ill. This was shown in a case in 1939 when a police officer in western Uganda was unable to detain a suspected lunatic roaming on the property of a European. When the police officer arrived, 'he found his relatives had already taken him away and they had chained him to a piece of wood. For that he could not possibly bring him and they are still guarding him'. ${ }^{62}$ The way forward was similarly unclear to those involved in a case in 1954, when a chief described how he wanted to detain a man who was 'a menace to the villagers in his area. He has already attacked a man with a panga and the man is in Kyenjojo Hospital'. ${ }^{63}$ His relatives, the chief stressed, 'wish to take him home and guard him'. Uncertain on the correct way to proceed, he asked the police for advice, and sent one of the relatives to explain their case further. ${ }^{64}$

While admission to the mental hospital depended on the judgements of the police and medical practitioners, families played a central role in determining committal, and their reasons for agreeing were often complex. While the Penal Code defined circumstances in which insanity could be used as a defence in criminal trials, relatives could still be pressured into providing compensation for actions taken by the mentally ill. It may have been a fear of such financial and legal responsibility that prompted Paskali B. to implore the District Commissioner (DC) of Toro in 1954 to 'help and send his brother [Alifunsi M.] to Mulago Hospital Kampala where he can be looked after' ${ }^{65} \mathrm{He}$ stressed that he was poor, had no wife to assist him and was 'unable to look after the mad man'. As the chief who forwarded his request noted, 'the mad man is doing damage to the property of other people'. ${ }^{66} \mathrm{He}$ had already killed four 
cattle, three goats and a dog, burnt a house, and was now 'taking away the property of other people by force'. Not only was there a threat that Alifunsi M. might 'kill people', but 'His brother is poor and asks for help to retain the mad man in jail to stop him damaging the property of other people'. ${ }^{67}$ The account hinted at fear of legal action as much as it stressed the burden of care. In requesting assistance, moreover, no distinction was made between confinement in a mental hospital or a jail. Not only did the man associate the activities of his brother with those of criminal lunatics - who despite the existence of Mulago Mental Hospital were still frequently kept in jails for up to a year-but he was keen to be relieved of responsibility for future crimes. ${ }^{68}$

A former chief from Bwamba, near Fort Portal, made similar claims in a letter to the DC Toro in 1960. He noted how his son, Leji W., had recently returned home, having left his wife and destroyed their house and belongings in the process. ${ }^{69}$ 'When he returned he was not well', the former chief continued: 'he started to beat people severely....He has beaten all my wives and children and their heads are full of sores caused by his beatings'. ${ }^{70}$ In addition, Leji W. had threatened to burn the houses of their neighbours, threatened his father, killed three cattle and caused relatives to flee. The former chief was writing to ask that 'this dangerous mad person may be kept by the Government.... One day he will kill a man and the Government will blame me'. ${ }^{71}$ The former chief wanted Leji W. to be removed away from home, 'where all people have ran away for fear of him'. ${ }^{72}$ Like the previous case, however, he drew no distinction between prison and the asylum-Mulago Mental Hospital was not necessarily a place for treatment, but it was certainly one of confinement, where families might be offered some form of relief from harm, and potential compensation claims.

Even in cases where relatives were aware of the existence of the mental hospital, it is clear from correspondence that they frequently lacked knowledge about the processes of committal. The 'correct' procedure caused some confusion for one man, who attempted to get his father, a former Saza (county) Head Clerk of Kinkizi, committed in 1960. Having written to the District Magistrate, Kigezi, describing how his father 'has now become so dangerous to the community that he has chased my mother, his wife, out of the home', he then contacted the DC Kigezi, to 'obtain necessary forms and detention order [sic.]' ${ }^{73}$ As a teacher, he felt unable to travel to Kabale to make arrangements in person and hoped the forms could be sent to him for completion and then forwarded with the 
patient. The testimony he provided was deemed to be 'quite useless' by the DC. Detention forms, as the DC noted, were not issued 'at request', but instead followed from a referral by the Saza Chief Kinkizi, the Police Station, Kabale, and the reports of two medical practitioners. ${ }^{74}$ Indeed, cases of suspected lunatics were frustrating for district administrators, who were unable to act until the proper procedure had been followed. ${ }^{75}$

In requesting the removal of relatives, families, like the patients themselves, were active agents in mental health care in ways that demanded recognition by the colonial administration. Even if formal requests for certification were unsuccessful, MOs and other officials were aware that they relied upon families to provide extra-institutional care. Patients who exhibited signs of mental illness at the CMS Mengo Hospital, Kampala, for example, might be transferred to Mulago Mental Hospital if they became violent, but this was determined primarily by the willingness and ability of relatives to care for them. Feriteita K., diagnosed with acute syphilitic dementia in 1940, and at Mengo Hospital for just over a month, alternated from being 'stuperous', 'uncomprehending', incontinent, and struggling violently, to 'Cannot be roused to cooperate at all, but not comatose in that she resists attention a little, usually turns over to her left side, sometimes has her eyes open'. ${ }^{76}$ In the end, her doctor decided that she was 'too demented to remain in [the] ward': she was defecating on the floor and chewing the bedclothes. Having raised the possibility of a transfer to Mulago Mental Hospital, however, her family decided to take her home. ${ }^{77}$ The availability of relatives was just as crucial in a case in 1938, this time involving a twenty-six-year-old female patient, Erivaniy N. Admitted complaining of headache and abdominal pain, she was said to be incapable of answering questions well and exhibited signs of 'mental disturbance', prompting a diagnosis of dementia. Within a day of admission, she suddenly became difficult to manage, with occasional outbursts of being 'Very noisy + uncontrollable'. ${ }^{78}$ After three weeks, Erivaniy N. was deemed too 'Noisy + troublesome at night' to remain, and as she had 'apparently no friends' and 'lives alone at home', she was transferred to Mulago. ${ }^{79}$ Similarly in 1941, Zalika N., diagnosed with 'acute toxic mania' following malaria, became progressively more unmanageable during her stay in hospital. After a week, she was recorded as being 'Restless, noisy, getting out of bed', and the following day was transferred to Mulago Mental Hospital. Having treated the malaria with quinine, and with no family available, her mental state was too problematic for the mission doctors to discharge her unaccompanied. ${ }^{80}$ 
It is not difficult to see why patients and their families were reluctant to accept committal to the mental hospital. Across the Uganda Protectorate, people not only had rich languages for mental illness, but a variety of strategies to deal with it-more than it is possible to cover fully here. Herbalists were often 'the first line of defence', living only short distances from patient's homes. When three women 'went mad' near Rukungiri in the late 1950s, according to a local elder, people in his village looked 'for medicinal herbs especially omwesamuryo [lit. the one that makes you sneeze] and olubuya' and then proceeded to tie them 'to their nose/nostrils'. This, he added, 'would calm them down'. ${ }^{81}$ In cases of madness near Lake Kyoga, families 'carved out a tree trunk and inserted in the leg' of the mad person. This tree was called enkomyo, meaning literally 'to stop / halt' ${ }^{82}$ Families could also seek the help of a healer who would try to appease the demands of the spirits who had brought on the madness. Abasawo abaganda (doctors) in Buganda called the balubaale (hero gods), before welcoming and celebrating them within the community. ${ }^{83}$ Within these frameworks of healing, patients and families were incorporated into therapies in ways that were neglected by the mental hospital. In the words of one traditional healer, working in Mpigi District, central Uganda, 'with all mental illness, the cause is spiritual and you have to appease and fulfil the ancestors' demands'. Key to success was the role of families and communities, not just in taking part in the treatment, but in acting quickly to prevent the condition from worsening. 'So when one gets a severe madness', she explained, 'the blame is on the parents for failure to fulfil ancestral demands early'. ${ }^{84}$ The mental hospital was, in such cases, a last resort, a place for patients who were beyond hope.

\section{Psychiatric Practices}

For many, admission meant long periods of silence and alienation from family networks of care. Not only was the distance and cost of transportation to Kampala prohibitive for most relatives, but communication was less than ideal. An important counterpoint to letters seeking the removal of a violent or difficult family member were requests sent in the months and years following admission, where families enquired about their relatives, often too far away to visit. In 1952, the brother of Kihika B., who had been admitted to Mulago Mental Hospital in 1944, approached the DC Toro to make enquiries into his whereabouts. ${ }^{85}$ Having forwarded 
the enquiry to the Superintendent of Mulago Mental Hospital, the DC Toro was subsequently informed that the patient had died of neurosyphilis six years previously, and was buried at Kololo, Kampala. ${ }^{86}$ There was no policy of repatriating bodies, and from the 1930s, those who died at Mulago Mental Hospital were also subject to post-mortem examinations, something at odds with cultural burial practices. ${ }^{87}$ In 1954, a similar request was made by two parents for information about their son, Kamugalwire B., who they knew had been admitted to Mulago Mental Hospital the previous year, but about whom they had not received any news. Young replied promptly, but in language that may have been difficult for Kamugalwire B.'s parents to understand. As Young noted, 'His physical health is satisfactory but mentally he is sullen, suspicious retarded [sic.] and without much insight' ${ }^{88}$ Lack of detailed information was also apparent in the response to the request for information made by another father, who reported how his son, Festo M., had run mad the previous year and been taken to Ndorwa Jail, southwest Uganda. While in jail 'his illness increased and he was sent to Mulago Hospital (where mad people are kept). And from then he has never heard of his son'. ${ }^{89}$ Festo M. was still alive, Young replied, but stated, briefly, that his behaviour 'is unreliable and his detention is still necessary'.90

The communication problems stemmed primarily from a lack of personnel and resources-specialist alienists had no time to compile regular reports on patients' progress - but it was also linked to the unreliability of the information available to administrators, MOs, and the superintendent of the mental hospital. In a case that may not have been uncommon, a police officer in Soroti described his frustration at encountering a suspected lunatic at his local station, who looked lost, perhaps being 'a Muganda or Musoga by tribe'. 'When I try to ask her name', he noted, 'she does not tell me, she said she was not given a name since she was born'. ${ }^{91}$ The problems caused by this lack of information could be devastating for both patients and families. Indeed, in July 1930, the DC Toro wrote to the Superintendent, Hoima Lunatic Asylum, to enquire about Zozimu R., who had not been heard of by relatives since being sent to the asylum from Kampala in May. ${ }^{92}$ No patient with that name could be found in the asylum registers, however. '[I]f admitted', the Assistant Superintendent noted briefly, 'he may have been described under another name'. ${ }^{93}$ No further information about Zozimu $\mathrm{R}$. could be traced in the correspondence - as far as the administration was concerned, he was lost. 
For all its claims to benevolence and care, psychiatry lacked the administrative capacity, medical expertise and cultural knowledge to be effective. This was particularly the case before 1949, when Mulago Mental Hospital was under the nominal supervision of J. P. Mitchell, Medical Superintendent of Mulago Hospital, and H. C. Trowell, Specialist Physician, who both had other, more pressing duties at Mulago Hospital and its medical school. ${ }^{94}$ But it was hardly much better when Mulago Mental Hospital had on its staff a full-time psychiatrist-first Young from 1949, then Gerald I. Tewfik from 1956. While Young had some experience of psychiatry within a colonial setting, having been Assistant Medical Superintendent of the Lunatic Asylum, Barbados, neither Young nor Tewfik spoke any of the languages in Uganda, relying on vague translations for case histories. They also knew little of the complexities of ideas about mental illness among different ethnic groups or how to understand the behaviours they saw. In this context, it is little surprise that most patients received no formal diagnosis at all. Of 304 patients admitted in the latter half of 1956, Tewfik was able to diagnose only 57 , of whom most had an identifiable organic cause $(28$ were diagnosed with GPI, while 10 were diagnosed with epilepsy). ${ }^{95}$ Lacking diagnoses, patients were treated largely symptomatically, with the psychiatrists lacking any clinical control. As Tewfik complained, 'Where electrical treatment was expected to be effective it frequently was not so; many recovered when they were not expected to do so, and others died for no reason known to the psychiatrist or to the pathologist at post mortem' ${ }^{96}$

From the late 1940s, despite lacking diagnoses, almost all patients would have undergone one of the psychiatric therapies on offer. This included insulin therapy, which may have resulted in deaths due to the inexperience of staff. ${ }^{97}$ ECT was also widely employed, with the number under treatment rising from 78 in 1948 to 230 in 1949 to 527 in $1950 .{ }^{98}$ And from 1953, Young introduced Largactil and prefrontal leucotomy, something that Young claimed proved useful in 'the most depraved and hopeless cases'. ${ }^{99}$ We should not assume that Young did not believe these therapies could offer real hope to patients-they represented the mainstream of psychiatry in the 1950s and 1960s. But they nevertheless served a practical purpose, playing an important role in managing patients who were otherwise difficult to control in a context where there was increasing pressure on accommodation and staff. Leucotomy, in particular, may have had a sedative effect that would have allowed for more patients to be discharged to their families as 'cured'. 100 
Writing about the benefits of the therapies on offer at Mulago Mental Hospital in 1957, Tewfik noted that two patients who had undergone leucotomies were 'greatly improved'. ${ }^{101}$ One was a male 'who had been a most difficult patient', but who 'improved markedly and was discharged to the care of his people within two months of operation'. 'The other', Tewfik added, 'is also considerably improved and will be discharged in the near future' 102

By 1958, Tewfik also employed chlorpromazine on a regular basis 'in the face of continued strain on accommodation', along with a number of other tranquilizing and sedative drugs 'supplied free by the manufacturers' for the purposes of controlled trials. ${ }^{103}$ Yet it was ECT that remained 'by far the most economical method', resulting, 'in suitable cases', in the 'most dramatic and far-reaching results'. ${ }^{104}$ In 1957, it was given to 588 patients (the total inpatient population for the year was 662). ${ }^{105}$ Most would receive between 4 and 12 treatments each, but a minority of patients received far more. ${ }^{106}$ Despite its widespread use, however, Tewfik conceded that it had little effect on the discharge rate, being more 'valuable as a sedative agent'. ${ }^{107}$ While no further details are given on these patients, evidence from elsewhere in colonial Africa indicates that these were likely patients who refused to follow the hospital routine, or who exhibited other behaviour that hospital attendants and the psychiatrist interpreted as particularly 'irrational' or difficult. Such was the case with Muchiri R., who was sent from a prison to Mathari Mental Hospital in 1956 'to see if mad'. On arrival, he was reported as being 'Rather turbulent' and 'will not sit down', only agreeing to answer questions 'after being told he will get E.C.T'. While he was not found to be suffering from any obvious mental illness, the admitting doctor, likely psychiatrist Edward Margetts, noted that he would 'ask prison if he is giving any trouble if so E.C.T'. In the following months, Muchiri R. returned to Mathari as an outpatient to receive four rounds of ECT. ${ }^{108}$

With the lack of specialist personnel at Mulago Mental Hospital, much of the day-to-day practice was left to hospital orderlies and attendants. They made observations, administered many of the treatments, and were charged with maintaining order. In 1946, 111 attendants (working in three shift patterns) were assigned to the mental hospital and many would have been required to attend a series of twenty-one lectures given by Baty, with the aid of a Luganda translator, so that 'the mental patients may gain the benefit of skilled treatment' ${ }^{109}$ Topics included a brief celebratory history of psychiatry, as seen at the beginning of this chapter, as 
well as notes on staff duties, first aid, the classification of mental illness and their symptoms, and observations. 'It is the duty of staff', Baty stressed, 'to observe the patients inside the wards and compounds, and prevent escapes and prevent the patients harming themselves and other patients and to see that the patients are properly cared for and clothed when in the compound'. ${ }^{110}$ Above all, staff were to maintain order and discipline, and to act as examples to patients, reflecting the 'moral management' practices that had developed in the UK during the nineteenth century. So, while 'some patients are unusually dirty, attendants should be unusually clean'. 111 They were instructed to be methodical, quiet and calm, and to cheerfully encourage patients to engage in basic 'occupational therapy', including gardening, ward, kitchen and laundry work, needlework, knitting, rug making, cotton growing and pottery. ${ }^{112}$

Throughout the colonial period, such occupational and physical therapies comprised the primary psychiatric treatments on offer at Mulago Mental Hospital. While Young, and his successor from 1956, Gerald I. Tewfik, acknowledged what they saw as an important psychotherapeutic role of traditional healers in treating mental illness, there was no attempt to bring traditional healers into the mental hospital. Yet patients may have drawn on the knowledge and skills of the hospital attendants and orderlies to access traditional forms of healing. At least one hospital attendant at Mulago in the early 1950s had the reputation of having the power of mayembe (charms), and worked locally in the parish as a wellknown traditional healer and money lender. ${ }^{113}$ Notorious for charging 150-200\% interest on loans, he was eventually brought before the parish lukiiko (council), however, and accused of an act of witchcraft. ${ }^{114}$ Certainly, those suffering from mental illness lived within frameworks for understanding mental illness that were completely different from the psychiatrists in charge, and the reliance on hospital attendants and orderlies in the running of the mental hospital may have allowed for flexibility and creativity in treatment.

Routines at Mulago Mental Hospital were strict, with staff reprimanded for breaches. Yet patients still shaped practices within the mental hospital, and lived lives that were not limited to acts of 'resistance'. Patients were constantly 'quarrelling' amongst themselves, making their independence and need for space known to the hospital authorities, who were forced to respond by making provisions for the extension of outside spaces. ${ }^{115}$ Those who refused to be confined, moreover, were 'continually escaping by climbing over the fence', not only prompting 
reassessment of the suitability of railings and hospital accommodation, but taking up time and resources. ${ }^{116}$ When the mental hospital was moved to a new site at Butabika, seven miles from Kampala, there was at first no boundary fence at all, and those dissatisfied with the hospital food started to visit the nearby village to request meals. ${ }^{117}$ Indeed, food proved a powerful way through which patients made their importance and needs felt. While the hospital authorities dedicated considerable time and effort to ensuring that the mental hospital diet struck a balance between cost, availability and the ideals of colonial nutritional science, the patients made it clear that food had important cultural and social significance that required consideration. As elsewhere in East Africa, food was an important marker of identity, with preparation, presentation and the act of eating representing a form of ritual. ${ }^{118}$ Such was the importance of plantains to the Ganda, the largest ethnic group at Mulago Mental Hospital, that the Luganda word for plantains, matooke, meant 'food', and represented a point of distinction between the Ganda and other ethnic groups, such as the Nyoro, whose staple food was millet. ${ }^{119}$ When, following a period of price inflation and matooke shortages in central Uganda in the 1940s and early 1950s, patients were served maizemeal for part of a year, they refused to eat for weeks, contributing to as many as 120 deaths and panic among the hospital authorities. ${ }^{120}$ Food mattered, and not for the reasons that the hospital administratorsobsessed with statistics and nutrition-believed that it did.

\section{Conclusion}

By the time an Australian expatriate psychiatrist, T. W. Murray, was appointed in 1960, the direction of psychiatry was starting to show signs of change. An ambitious scheme to develop psychiatry as a specialism for African doctors was being discussed by Makerere University College and the colonial government. Stephen B. Bosa, Uganda's first psychiatrist, was at the Maudsley Hospital, London, working towards his Diploma in Psychological Medicine (DPM), and the first formal attempt to extend the reach of psychiatry beyond the mental hospital had been made with the opening of a psychiatric ward at Soroti Hospital. Overcrowding at Mulago Mental Hospital, along with pressures on space caused by the expansion of other specialist departments at Mulago Hospital, had also seen plans to move the mental hospital further from Kampala, with access to 1000 acres of land 'to ensure that the inmates have privacy, and 
can be usefully employed in work that will help in their cure'. ${ }^{121}$ The new hospital was built at Butabika, seven miles outside of Kampala, with views over Lake Victoria. It was still in the process of construction when opened to patients in 1955, but by 1964, the final (criminal) patients had been transferred to a new specialist unit, and Mulago Mental Hospital was closed for good. Regarded as something of a parting gift from the British at Independence, Butabika Hospital would be the face of psychiatry during the years of decolonisation.

The growth and organisation of psychiatry in colonial Uganda had been premised on and shaped by more than a singular intention to define and subdue deviant populations. The need for a mental hospital had at first been a practical and moral issue, driven by scandal and the centralising tendencies of the 1920s, then later framed as a medical concern, with desires to break the association between lunacy and crime and to treat mental illness by 'modern' means. Despite the steady expansion of psychiatry throughout the colonial period, psychiatric practice remained limited: constrained by location, finances and few specialist personnel, psychiatry lacked the geographical reach and therapeutic power to be effective. It was still, for most, a last resort, reserved primarily for the most 'urgent' or difficult cases. In the absence of confidence or certainty in the mental hospital, patients and their families continued to respond to the idea of 'confinement' in different ways. For some, the mental hospital was simply a place for the most difficult 'lunatics', little different from a prison, and to be used when the financial responsibility became too great, or the patient too violent. For others, admission to a mental hospital was an alienating experience for both patient and family-a place where communication was limited and culturally sanctioned forms of healing could not be formally accessed. Young complained to readers of the Uganda Argus in 1955 that there were 'several factors working against the recovery of the mentally sick in Uganda', of which 'the laudable one of wanting to look after the mentally sick in the family circle as long as possible' was key. ${ }^{122}$ He pointed to a 'widely held' belief that had emerged around psychiatry that saw the mental hospital as a place of permanent confinement. This belief, 'built on superstition', held 'that to allow a relative to enter a mental hospital was as good as signing his death warrant'. ${ }^{123}$ These perceptions of psychiatry would persist beyond Independence in 1962, proving difficult, if not impossible, for psychiatrists to overcome. 
The marginal nature of institutional psychiatry in colonial Uganda has important implications for our understanding of the relationship between psychiatry and decolonisation. Despite ongoing concern about rising numbers of inpatients at Mulago and then Butabika Hospital, in the context of Uganda's total population, which in 1959 stood at an estimated 6.5 million, these numbers were extremely small. ${ }^{124}$ Psychiatry was not, then, in a position where it had to face questions of what to do with vast numbers of inpatients, as it would have to do in Europe and the USA in the context of deinstitutionalisation. For all its flaws, moreover, the mental hospital, as the sole face of psychiatry, remained the only institution available to psychiatrists in the years immediately leading up to, and following Independence. Rather than engage in a process of dismantling an institution that had limited geographical and cultural reach, the more pressing question, was how to build up and extend the reach of psychiatry: how to make it culturally relevant, how to help people who lived far from the hospital walls, and how to convince them to turn to psychiatry in times of distress.

\section{Notes}

1. As cited in D. Zeller, 'The Establishment of Western Medicine in Buganda' (Unpublished PhD thesis, Columbia University, 1971), p. 333.

2. Bodleian Library, University of Oxford (BOD) Mss.Afr.s.1872(84) (Papers of Philip William Hutton), ff. 30-31, 'Some Comments on African Attitudes to European Medicine'.

3. BOD Mss.Afr.s.1589 (Papers of Charles Baty), 'Lectures \& Treatments', f. 9, 'Lecture 1-On Study', n. d.

4. Ibid.

5. Ibid.

6. M. Vaughan, Curing Their Ills: Colonial Power and African Illness (Cambridge, 1991), p. 120.

7. Y. Pringle, 'Crossing the Divide: Medical Missionaries and Government Service in Uganda, 1897-1940', in Anna Greenwood, ed., Beyond the State: The Colonial Medical Services in British Africa (Manchester, 2015). See also: J. Kuhanen, Poverty, Health and Reproduction in Early Colonial Uganda (Joensuu, 2005).

8. On medical missionaries and mental illness, see Y. Pringle, 'Neurasthenia at Mengo Hospital, Uganda: A Case Study in Psychiatry and a Diagnosis, 1906-50', The Journal of Imperial and Commonwealth History 44(2) (2016), pp. 241-262. 
9. On medical training in Uganda, see especially J. Iliffe, East African Doctors: A History of the Modern Profession (Kampala, 2002); A. M. Odonga, The First Fifty Years of Makerere Medical School and the Foundation of Scientific Medical Education in East Africa (Kampala: Marianum Press, 1989).

10. See, for example, the remarks in BOD Mss.Afr.S.1872(144A) (Hugh Trowell Papers), 'Dr. Hugh Trowell OBE, MD, FRCP', p. 12. See also: M. Lyons, 'The Power to Heal: African Medical Auxiliaries in Colonial Belgian Congo and Uganda', in D. Engels and S. Marks, eds., Contesting Colonial Hegemony: State and Society in Africa and India (London, 1994).

11. G. C. Beuschel, 'Shutting Africans Away: Lunacy, Race and Social Order in Colonial Kenya, 1910-1963' (Unpublished PhD thesis, SOAS, University of London, 2001), p. 127.

12. A. R. Cook, Uganda Memories, 1897-1940 (Kampala, 1945), p. I; W. D. Foster, The Early History of Scientific Medicine in Uganda (Nairobi, 1970), pp. 93-107; D. M. Haynes, 'Framing Tropical Disease in London: Patrick Manson, Filaria Perstans, and the Uganda Sleeping Sickness Epidemic, 1891-1902', Social History of Medicine 13(3) (2000), pp. 467-493; D. Neill, 'Paul Ehrlich's Colonial Connections: Scientific Networks and Sleeping Sickness Drug Therapy Research, 1900-1914', Social History of Medicine 22(1) (2008), pp. 61-77.

13. K. A. Hoppe, Lords of the Fly: Sleeping Sickness Control in British East Africa, 1900-1960 (Westport, CN, 2003), p. 1. On the development of the Colonial Medical Service in Uganda during this period, see A. Beck, A History of the British Medical Administration of East Africa: 19001950 (Cambridge, MA, 1970), Ch. 2.

14. The National Archives, Kew, United Kingdom (TNA) CO 536/32, 62 (Blue Book + Report, 1908-1909).

15. A. R. Cook, 'A Visit to a Branch Dispensary and a Sleeping Sickness Camp in Uganda', Mercy and Truth 148 (1909), p. 108.

16. BOD Mss.Afr.s.1091 Box 3 File 1 (Baker Papers), f. 11, 'A Night and Day in a "Sleeping Sickness" Camp', p. 3.

17. TNA CO 536/31, 38571 (Sleeping Sickness), 'Official Report on the Measures Adopted by the Uganda Administration in Dealing with "Sleeping Sickness" in the Protectorate, 17 November 1909', para. 52.

18. TNA CO 536/6 no. 49 (Report on the Bankruptcy and Lunacy Ordinance, 1906). In this year, four people were certified as insane under the new legislation. TNA CO 536/14 no. 110 (Report on Legal Dept. 1906. Judge Carter), p. 3.

19. TNA CO 536/6 no. 49 (Ordinance No. 41906 "Bankruptcy and Lunacy" Submits). Also TNA CO 536/2 no. 61 ([1] Sergt J. Sayers, 
Inspr of Police. [2] Sergt Pugh, Inspr of Police), Medical Certificate dated 5 June 1905.

20. TNA CO 536/8 no. 207, letter from H. Hesketh Bell, H.M. Commissioner, to the Earl of Elgin and Kincardine, l November 1906, p. 1.

21. TNA CO 536/8 no. 207, letter from H. Hesketh Bell, H.M. Commissioner, to the Earl of Elgin and Kincardine, l November 1906, pp. 1-3.

22. TNA CO 536/163/2; TNA CO 536/165/18; TNA CO 822/76/12 (Lunacy).

23. Uganda National Archives (UNA) A46/1120 (Hoima Prison: Leper and Lunatic Prisoners), letter from Captain Chiddick, Commissioner of Prisons, Kampala, to Chief Secretary, Entebbe, 24 July 1913.

24. TNA CO 536/62 no. 42541 (Prisons-Inspection Report 1912), 'Report of the Inspector General of Police and Prisons on the Uganda Government Prisons for the Year 1912', para. 2.

25. Uganda Protectorate, Blue Book for the Year Ended 31st March, 1915 (Entebbe, 1915), p. Dal; TNA CO 536/104 no. 604 (Death Rate among Prisoners), letter from C. A. Wiggins to Chief Secretary, Entebbe, 30 September 1920; TNA CO 536/104 no. 604, 'Report on Lunatic Asylum, Hoima', p. 3.

26. Uganda Protectorate, Annual Medical and Sanitary Report for the Year Ended 31st December, 1923 (Entebbe, 1924), pp. 9-10.

27. Beck, A History of the British Medical Administration, Ch. 4; C. P. Youe, 'Peasants, Planters and Cotton Capitalists: The "Dual Economy" of Uganda', Canadian Journal of African Studies 12(2) (1978), pp. 163-184.

28. Pringle, 'Crossing the Divide.'

29. On attempts to combat venereal disease, see especially C. Summers, 'Intimate Colonialism: The Imperial Production of Reproduction in Uganda, 1907-1925', Signs 16(4) (1991), pp. 787-807; M. W. Tuck, 'Syphilis, Sexuality, and Social Control: A History of Venereal Disease in Colonial Uganda' (Unpublished PhD thesis, Northwestern University, 1997). On the staffing of the Colonial Medical Service more generally, see A. Crozier, Practising Colonial Medicine: The Colonial Medical Service in British East Africa (London, 2007).

30. UNA C1266 (Medical Organisation of Medical Units at Kampala), memorandum by Major Keane entitled 'Asiatic Hospital-Kampala', May 1928. Such was the importance of the tendency towards centralisation that in 1936 officials considered relocating the Medical Headquarters from Entebbe to Kampala. See UNA Jl/23 (Medical Headquarters-Transfer of, to Kampala). 
31. UNA C0524 (Miscellaneous-Lunatics, Death of, in Kampala Jail); A. R. Dunbar, A History of Bunyoro-Kitara (Nairobi, 1965), pp. 121-122.

32. Albert Cook Memorial Library, Makerere University (ACMM), Mengo Hospital Correspondence, letter from Major Keane, Director of Medical and Sanitary Services, Entebbe, Uganda, to Dr. Cook, 11 September 1930.

33. Ibid.

34. Ibid.

35. Uganda Protectorate, Annual Report of the Medical Department for the Year Ended 31st December, 1930 (Entebbe, 1931), p. 47.

36. J. Sadowsky, Imperial Bedlam: Institutions of Madness in Colonial Southwest Nigeria (Berkeley and Los Angeles, 1999), Ch. 2.

37. 'A Lunatic at Large', Uganda Herald, 3 July 1935, p. 10.

38. Kabale District Archives (KDA) (Circulars), circular memorandum from Chief Secretary entitled 'Mulago Mental Hospital, 25 March 1936'; Mountains of the Moon University, Fort Portal (MMU) MED 1079(295) (Lunatics), f. 1, circular memorandum from J. Hope Reford to all Medical Officers, 8 December 1926; Soroti District Archives (SDA) JUD 1/2 (Lunatics), f. 22, letter from J. S. Champion, Ministry of Health and Medical Headquarters, Entebbe, to M. Rogers, DC Teso, 31 March 1960; ACMM, Medical Department Circulars, circular memorandum entitled 'Admissions to Mental Hospitals', 20 November 1957.

39. MMU MED 1079(295), f. 1, circular memorandum from J. Hope Reford to all Medical Officers, 8 December 1926.

40. UNA D107/12 (Lunatics: Transport of Mental Patients), ff. 4-5, letter from Lieut.-Colonel, Commissioner of Police, to Director of Medical Services, Entebbe, 10 February 1942.

41. 'Eddwaliro Ly'abalalu', Gambuze, 6 January 1933, p. 2.

42. 'Notes by the Way: A Weekly Commentary on Current Affairs', Uganda Herald, Wednesday 14 August 1935, p. 13.

43. J. F. Wood, 'A Half Century of Growth in Ugandan Psychiatry', Uganda Atlas of Disease Distribution (Kampala, 1968), p. 118.

44. Uganda Protectorate, Anmual Report of the Medical Department for the Year Ended 31st December, 1956 (Entebbe, 1957), p. 49.

45. Uganda Protectorate, Annual Report of the Medical Department for the Year ended 31st December, 1938 (Entebbe, 1939), p. 55; Uganda Protectorate, Annual Report of the Medical Department, 1956, p. 49.

46. See, for example, G. I. Tewfik, 'Mulago Hospital Clinical Staff Meeting April 26, 1958: The African Mind Fact or Myth?’ East African Medical Journal 35(8) (1958), pp. 512-513. 
47. Uganda Protectorate, Annual Report of the Medical Department for the Year Ended 31st December, 1951 (Entebbe, 1952), p. 60.

48. UNA D107/12, ff. 4-5, letter from Lieut.-Colonel, Commissioner of Police, to Director of Medical Services, Entebbe, 10 February 1942.

49. Uganda Protectorate, Anmual Report of the Medical Department, 1956, p. 49.

50. H. G. Egdell, 'A Rural Psychiatric Service in Uganda', Psychopathologie Africaine 6(1) (1970), p. 89.

51. G. I. Tewfik, 'Problems of Mental Illness in Uganda', Mental Disorders and Mental Health in Africa South of the Sahara: CCTA/CSA-WFMHWHO Meeting of Specialists on Mental Health (Bukavu, 1958), p. 63.

52. TNA CO 536/165/18, f. 91, 'Medical Certificate'.

53. TNA CO 536/165/18, f. 86, 'Enclosure K' of Lunacy Cause No. 12 of 1930, p. 2.

54. TNA CO 536/165/18, f. 87, 'Enclosure K' of Lunacy Cause No. 12 of 1930 , p. 3.

55. TNA CO 536/165/18, ff. 95-98, letter to the Chief Secretary's Office, Entebbe, 23 April 1931.

56. TNA CO $536 / 179 / 1$, f. 7 , note by J. S. Macpherson, 1 November 1933.

57. TNA CO 536/179/1, ff. 43-45, letter dated 6 September 1933.

58. TNA CO 536/179/1, ff. 39-42, letter from the Governor of Uganda, 3 October 1933.

59. TNA CO 536/179/1, f. 4 , note by Mr. Duncan.

60. TNA CO 536/165/18, ff. 56-60, 'Enclosure A'.

61. ACMM, Mengo Hospital Case Notes, 1938, Vol. 8, No. 2157, p. 647.

62. MMU 471(118) (Loc Govt-Lunatics \& Vagrants), f. 48, letter addressed to DC Toro, 14 April 1939; MMU 471(118), f. 47, letter from DC Toro, 11 April 1939.

63. MMU JUD 4(1) (Lunacy), f. 22, letter addressed to O.C. Police, Toro, 13 September 1954.

64. Ibid.

65. MMU JUD 4(1), f. 26, letter addressed to DC Toro, 21 September 1954.

66. Ibid.

67. Ibid.

68. Uganda Protectorate, Annual Report on the Treatment of Offenders for the Year Ended 31st December, 1954 (Entebbe, 1955), pp. 13-14.

69. MMU JUD 4(1), f. 127, letter addressed to DC Toro, 15 June 1960.

70. Ibid.

71. Ibid.

72. Ibid. 
73. Kabale District Archives (KDA) JUD 1/3 I (Lunacy), f. 247, letter addressed to DC Kigezi, 29 October 1960.

74. KDA JUD 1/3 I, f. 248, letter from DC Kigezi, 3 November 1960.

75. MMU 471(118), f. 46, letter from DC Toro to Katikiro of Toro, 26 July 1938.

76. ACMM, Mengo Hospital Case Notes, 1940, Vol. 4, No. 1175, p. 707.

77. Ibid.

78. ACMM, Mengo Hospital Case Notes, 1938, Vol. 4, No. 1009, p. 347.

79. Ibid.

80. ACMM, Mengo Hospital Case Notes, 1941, Vol. 5, No. 1629.

81. Interview with Ankole male, approximately 7l years old (RUK-06), Butinde Village, Kebisoni Sub-County, Rukungiri District, 5 July 2011.

82. Interview with Ganda male, approximately 92 years old (KAY-03), Kawuku, Kayunga District, 3 June 2011.

83. J. Orley, Culture and Mental Illness (Nairobi, 1970), pp. 20-24; N. Kodesh, 'Networks of Knowledge: Clanship and Collective WellBeing in Buganda', The Journal of African History 49(2) (2008), pp. 197-216.

84. Interview conducted with P. Nabuto (MPG-04), Buyijja, Mpigi District, 19 October 2011.

85. MMU JUD 4(1), f. 11, letter from DC Toro to Superintendent, Mental Hospital, Mulago, 4 December 1952.

86. MMU, JUD 4(1), f. 12, copy of letter from Medical Superintendent, Mulago, to DC Toro, 2 August 1946.

87. Post-mortem examinations were conducted for research purposes. See, for example, W. R. Billington, 'Neurosyphilis in Natives of East Africa' (Unpublished MD thesis, University of Cambridge, 1945).

88. KDA JUD 1/3 I, f. 29, letter from G. Campbell Young to DC Kigezi, 4 January 1954.

89. KDA JUD 1/3 I, f. 4, letter from Yeremiya Bigombe, for Saza Chief Ndorwa, to DC Kigezi, 10 May 1954.

90. KDA JUD 1/3 I, f. 7, letter from G. Campbell Young to DC Kigezi, 19 May 1954.

91. SDA JUD 1/2, f. 26, letter addressed to O.C. Police, Soroti Teso, 8 April 1960.

92. MMU MED 1079(295), f. 98, letter from DC Toro to Superintendent, Lunatic Asylum, Hoima, 11 July 1930; MMU MED 1079(295), f. 97, note addressed to DC Toro, 8 July 1930. 
93. MMU MED 1079(295), f. 99, letter from Assistant Superintendent, Mental Hospital, to DC Toro, 18 July 1930.

94. BOD Mss.Afr.s.1872(144B) (Hugh Trowell Papers), 'Transcript of Conversations Between Hugh Trowell and Elizabeth Bray', p. 34; BOD Mss.Afr.s.1589, 'Correspondence-Uganda Govt.', letter from Crown Agents, London to Charles Baty, 9 March 1940.

95. G. I. Tewfik, 'Psychoses in Africa', Mental Disorders and Mental Health in Africa South of the Sahara: CCTA/CSA-WFMH-WHO Meeting of Specialists on Mental Health (Bukavu, 1958), p. 131.

96. Ibid., p. 127

97. Uganda Protectorate, Annual Report of the Medical Department, 1956, p. 49.

98. Uganda Protectorate, Annual Report of the Medical Department for the Year Ended 31st December, 1950 (Entebbe, 1951), p. 31.

99. Uganda Protectorate, Annual Report of the Medical Department for the Year Ended 31st December, 1954 (Entebbe, 1955), p. 36.

100. J. D. Pressman, Last Resort: Psychosurgery and the Limits of Medicine (San Francisco, 1998).

101. Uganda Protectorate, Annual Report of the Medical Department for the Year Ended 31st December, 1957 (Entebbe, 1958), p. 46.

102. Annual Report of the Medical Department for 1957, p. 46.

103. Uganda Protectorate, Annual Report of the Medical Department for the Year Ended 31st December, 1958 (Entebbe, 1959), p. 61.

104. Uganda Protectorate, Annual Report of the Medical Department, 1958, p. 61.

105. G. I. Tewfik, 'Problems of Mental Illness in Uganda', p. 68.

106. G. I. Tewfik, 'Low Incidence of Fractures Among Africans Following Electro-Convulsive Therapy', West African Medical Journal 9(1) (1960), p. 26.

107. Tewfik, 'Psychoses in Africa', p. 134.

108. Mathari Hospital Records Project, Nairobi, AF/M.132/55.

109. BOD Mss.Afr.s.1589, 'Lectures \& Treatments', f. 12, 'Lecture l'.

110. BOD Mss.Afr.s.1589, 'Lectures \& Treatments', f. 13, 'Objects of the Mental Hospital'.

111. BOD Mss.Afr.s.1589, 'Lectures \& Treatments', f. 11, 'Chief Duties of Attendants'.

112. UNA J142 (Mental Hospital: Occupational Therapy for the Treatment of Patients); Uganda Protectorate, Annual Report of the Medical Department for the Year Ended 31st December, 1937 (Entebbe, 1938), 
p. 51; Uganda Protectorate, Annual Report of the Medical Department for the Year Ended 31st December, 1946 (Entebbe, 1949), pp. 48-49; Uganda Protectorate, Annual Report of the Medical Department for the Year Ended 31st December, 1948 (Entebbe, 1950), p. 48; Uganda Protectorate, Annual Report of the Medical Department, 1949, p. 44.

113. A. W. Southall and P. C. W. Gutkind, Townsmen in the Making: Kampala and Its Suburbs (Kampala, 1957), p. 206.

114. Ibid., pp. 149-150.

115. BOD Mss.Afr.s.1589, 'Correspondence', ff. 26-30, letter from Mental Hospital, Mulago, to Director of Medical Services, Entebbe, 31 October 1946, p. 1.

116. Ibid.

117. Interview with two Ganda females (BUT-01), Butabika, 16 May 2011; Interview with Ganda male (BUT-03), Butabika, 23 May 2011; Interview with Ganda female (BUT-04), Butabika, 23 June 2011.

118. See M. Graboyes, 'Chappati Complaints and Biriani Cravings: The Aesthetics of Food in Colonial Zanzibari Institutions', Journal of Eastern African Studies 5(2) (2011), pp. 313-328.

119. J. J. Jørgensen, Uganda: A Modern History (London, 1981), p. 37.

120. Uganda Protectorate, Annual Report of the Medical Department, 1954, p. 36.

121. BOD Mss.Afr.s.1589, 'Correspondence', ff. 17-18, 'Extract from Report and Recommendation on the Post-War Development of the Medical Services', p. 1.

122. ' $£ 90,000$ Hospital Wing at Butabika Opened', Uganda Argus, 11 June 1955 , p. 5 .

123. Ibid.

124. Uganda Government, The First Five-Year Development Plan (Entebbe, $1962)$, p. 2. 
Open Access This chapter is licensed under the terms of the Creative Commons Attribution 4.0 International License (http://creativecommons.org/licenses/ by $/ 4.0 /)$, which permits use, sharing, adaptation, distribution and reproduction in any medium or format, as long as you give appropriate credit to the original author(s) and the source, provide a link to the Creative Commons license and indicate if changes were made.

The images or other third party material in this chapter are included in the chapter's Creative Commons license, unless indicated otherwise in a credit line to the material. If material is not included in the chapter's Creative Commons license and your intended use is not permitted by statutory regulation or exceeds the permitted use, you will need to obtain permission directly from the copyright holder.

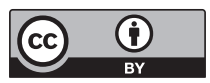

